\title{
PROSPEK PERSEROAN PEMEGANG SAHAM TUNGGAL TANPA PERKECUALIAN UNTUK KEMUDAHAN BISNIS
}

\author{
A'an Efendi \\ Fakultas Hukum Universitas Jember \\ email: aan_efendi.fh@unej.ac.id
}

disampaikan 15/01/2020 - di-review 31/05/2020 - diterima 03/12/2020

DOI: $10.25123 /$ vej.3694

\begin{abstract}
As a general rule, economic enterprises or companies should be established based on the principle of capital association and agreement. In contrast, Law No. 40 of 2007 re. Limited Liability Companies, provide exemptions to both principles. On the basis of this observation the issue discussed in this articles are: (1) why is the exemption provided only for certain forms of economic enterprises or companies; (2) is this exemption to the rule justified, perceived from the principle of equality; and (3) what are the justification for allowing the establishment of a limited liability company with a single investor (sole ownership). Using a juridical doctrinal approach the answer to the above questions are: (1) exemption are granted for state owned companies, established and regulated under public law; (2) the exemption is unjust as it discriminates and allowed for discriminative treatment; and (3) the practice of establishing a limited liability company by a single shareholder is a long standing practice.
\end{abstract}

Keywords:

single shareholder limited liability, principle of justice and equality, the law of limited liability companies

\begin{abstract}
Abstrak
Perseroan dibangun atas dasar prinsip persekutuan modal dan perjanjian. Kedua prinsip ini merupakan satu rangkaian yang tidak terpisahkan. Kendati demikian, Undang-Undang No. 40 tahun 2007 tentang Perseroan Terbatas mengenyampingkan kedua prinsip tersebut. Beranjak dari pengamatan ini, ditelaah tiga masalah: (1) mengapa pengeculian ini hanya berlaku untuk bentuk perseroan tertentu?, (2) apakah pengecualian ini dapat dibenarkan dari sisi keadilan-kesetaraan; dan (3) apa ratio legis dari pembolehan pembentukan perseroan dengan pemegang saham tunggal? Dengan menggunakan pendekatan yuridis doctrinal jawaban yang ditemukan adalah (1) kedua prinsip tidak diberlakukan terhadap Badan Usaha Milik Negara karena pengaturan pembentukan, pengelolaan dan sumber modal diatur oleh hukum public; (2) pengecualian ini tidak dapat dibenarkan dari sisi keadilan karena bersifat diskriminatif dan mengabaikan prinsip kesamaan dihadapan hukum dan (3) peluang mendirikan perseroan dengan pemegang saham tunggal diambil atas dasar praktik ini telah diterima masyarakat.
\end{abstract}

Kata Kunci: perseroan pemegang saham tunggal, prinsip kesetaraan, undang-undang perseroan terbatas

\section{Pendahuluan}

Berdasarkan Pasal 1 angka 1 Undang-Undang Nomor 40 Tahun 2007 tentang Perseroan Terbatas (untuk seterusnya disebut UUPT), Perseroan Terbatas (untuk seterusnya disebut Perseroan) adalah badan hukum yang merupakan persekutuan modal, didirikan berdasarkan perjanjian, melakukan kegiatan usaha 
dengan modal dasar yang seluruhnya terbagi dalam saham dan memenuhi persyaratan yang ditetapkan dalam UUPT serta peraturan pelaksanaannya. Berpijak pada ketentuan Pasal 1 angka 1 angka 1 UUPT tersebut, Perseroan memiliki karakteristik: (1) Perseroan adalah badan hukum persekutuan modal; ${ }^{1}$ (2) pendiriannya berdasarkan perjanjian; (3) melakukan kegiatan usaha ${ }^{2}$; (4) modal dasar Perseroan seluruhnya terbagi dalam saham; ${ }^{3}$ dan (5) memenuhi persyaratan UUPT dan peraturan pelaksanaannya.

Dari karakteristik Perseroan tersebut terdapat dua prinsip dasar dalam Perseroan, yaitu prinsip persekutuan modal dan prinsip perjanjian. Dua prinsip ini suatu rangkaian yang tidak terpisahkan. Perseroan adalah persekutuan modal oleh karena itu pendiriannya dengan perjanjian dan Perseroan harus didirikan dengan perjanjian karena Perseroan adalah persekutuan modal. Prinsip persekutuan modal dan prinsip perjanjian dikuatkan kembali oleh Pasal 7 ayat (1) dan (2) dan ditegaskan dalam penjelasan Pasal 7 ayat (1) bahwa sebagai badan hukum, pendirian Perseroan berdasarkan perjanjian dan mempunyai lebih dari 1 (satu) orang pemegang saham.

1 Menurut Marshall, badan hukum adalah manusia semu yang tidak terlihat dan tidak dapat diraba, dan badan hukum itu adalah suatu 'kepribadian', memiliki kekuasaan untuk mengggugat dan dapat digugat serta usianya tidak bergantung pada para pengurusnya. David Millon, Theories of the Corporation, Duke Law Journal, Vol. 1990, No. 201, hlm. ,206. Perseroan sebagai badan hukum berarti "the company is separate person in law" dan Perseroan adalah "the subject of rights and duties" sehingga Perseroan dapat menjadi pemegang kepemilikan atas benda, melakukan tindak pidana, dan membuat kontrak. Lihat dan baca, Nicholas Bourne. Essential Company Law, Third Edition, Cavendish Publishing Limited, London and Sydney, 2000, hlm., 1, ; Bryant Smith, Legal Personality, Suspicions News Magazine, Vol. 12, No. 1, 1926, hlm. 80; dan John M.B. Balouziyeh, A Legal Guide to United States Business Organizations The Law of Partnership, Corporations, and Limited Liability Companies, Second Edition, Springer, Heidelberg, 2013, hlm., 47.

2 Perseroan adalah adalah business entity yang dibentuk sebagai alat untuk melakukan kegiatan bisnis yang tujuannya memperoleh keuntungan bagi pendiri atau pemegang sahamnya. Anthony Mancuso, Nolo's Quiick LLC, 4th Edition, Nolo, California, 2007, hlm., 14.

3 Sero atau saham merupakan ciri khas Perseroan yang membedakannya dengan bentuk badan usaha lainnya. Nama "Perseroan" itu sendiri memang berarti ada sero atau saham dalam Perseroan, sedangkan "terbatas" menunjukkan terbatasnya tanggung jawab organ Perseroan sebagai konsekuensi logis perseroan sebagai subjek hukum yang mandiri. Pertanggungjawaban yang terbatas dalam Perseroan adalah mekanisme untuk melindungi pemilik dan pemegang saham Perseroan. Pemegang saham tidak dapat dibebani tanggung jawab atas hutang dan kewajiban Perseroan yang melebihi nilai sahamnya. Marie-Laure Djelic, When Limited Liability was (Still) an Issue: Mobilization and Politics of Signification in 19thCentury England, Organization Studies Vol.34, No. 5-6, 2013, hlm., 596. 
Namun demikian, prinsip persekutuan modal dan prinsip perjanjian ini tidak berlaku absolut. Untuk Perseroan sebagaimana diatur dalam Pasal 7 ayat (7) UUPT dikecualikan dari berlakunya dua prinsip tersebut atau dengan kata lain, UUPT mengakui Perseroan Pemegang Saham Tunggal (untuk seterusnya disebut PPST). Prinsip Perseroan secara umum tetap berdasarkan prinsip persekutuan modal dan prinsip perjanjian dan di luar Perseroan sebagaimana dimaksud Pasal 7 ayat (7) UUPT tertutup pintu untuk didirikan PPST.

Pendirian Perseroan selain Perseroan dalam ketentuan Pasal 7 ayat (7)UUPT mengharuskan pendirinya bermitra dan membagi kepemilikan sahamnya dengan pihak lain sebagai konsekuensi logis dari prinsip persekutuan modal dan prinsip perjanjian. Praktiknya, tidak setiap pendiri Perseroan ingin bekerja sama dengan pihak lain tetapi terikat oleh persyaratan dalam UUPT. Praktiknya pula, untuk menghindari ketentuan UUPT, Perseroan didirikan dimana secara formal telah sesuai dengan prinsip persekutuan modal dan prinsip perjanjian tetapi esensinya adalah PPST.

Anner Mangatur Sianipar mencatat beberapa Perseroan yang pendirian dan ketentuan kepemilikan sahamnya sesuai dengan UUPT tetapi esensinya adalah PPST, yaitu:

1. PT. Bumihutani Lestari yang berdasarkan akta notaris perubahan anggaran dasar terakhir menunjukkan hanya ada 2 (dua) pesero yaitu PT. Bumi Langgeng Perdanatrada memiliki sebanyak 125.300.061 (seratus dua puluh lima juta tiga ratus ribu enam puluh satu) lembar saham senilai Rp. 125. 300.061 .000 (seratus dua puluh lima miliar tiga ratus juta enam puluh satu ribu) dan PT. Pranabumi Pratama sebanyak 1 (satu) lembar saham senilai Rp. 1.000 (seribu rupiah).

2. PT. Maspion Industrial Estate yang berdasarkan perubahan anggaran dasar terakhir memiliki 2 (dua) pemegang saham, yaitu PT. Bumi Maspion memiliki sebanyak 1.099 .999 (satu juta sembilan puluh sembilan ribu sembilan ratus sembilan puluh sembilan) lembar saham dengan keseluruhan nilainya sebesar Rp. 1.099.999.000,- (satu milyar sembilan puluh sembilan juta sembilan ratus sembilan puluh sembilan ribu rupiah) dan PT. Maspion Investindo dengan kepemilikan hanya atas 1 (satu) lembar saham.

3. PT. Kaliwangi Chasasi Dharma Putra yang didirikan pada 27 Oktober 1999 di Jakarta oleh Ir. Mohammad Gamal Sugiarto dan Dra. Ekawati Praharti. Setelah Perseroan memperoleh status badan hukum, 2 (dua) pendiri tersebut menikah tanpa membuat perjanjian kawin untuk 
memisahkan harta mereka. Perseroan ini menjalankan usahanya sampai sekarang dan pemegang sahamnya hanya suami istri tersebut. ${ }^{4}$

Pendirian dan kepemilikan saham Perseroan oleh 2 (dua) orang atau lebih tetapi esensinya merupakan PPST bukan hal baru dalam hukum Perseroan. Kasus Salomon pada 1892 adalah contohnya. Aaron Salomon adalah seorang pedagang kulit yang sukses khususnya sepatu kulit. Untuk beberapa tahun Salomon menjalankan bisnisnya sebagai pebisnis tunggal (sole trader). Pada 1892, anak Salomon tertarik untuk ambil bagian dari bisnis Salomon sehingga akhirnya diputuskan dibentuk Perseroan bernama Salomon \& Co. Ltd. Pada saat itu, untuk membentuk Perseroan paling sedikit harus oleh 7 (tujuh) orang pemegang saham. Salomon memiliki 20.001 dari 20.007 lembar saham, sisanya yang 6 (enam) lembar saham dimiliki oleh pemegang saham lainnya yaitu istri, anak perempuan, dan 4 (empat) anak laki-laki Salomon. Dari kasus Salomon ini dapat dipetik satu aspek, yaitu melegitimasi konsep PPST dimana bisnis yang dikontrol hanya oleh satu individu dapat dijadikan Perseroan yang terpisah dari pemegang saham dengan satu individu itu sebagai pemegang sahamnya, yang itu dilindungi dari tuntutan para kreditor perusahaan. ${ }^{5}$ Salomon \& Co. Ltd dikatakan sebagai PPST karena hanya Salomon yang "real" sebagai pemegang saham sementara anggota keluarganya yang lain hanya untuk melengkapi persyaratan pendirian Perseroan. Dari Kasus Salomon dapat dipetik kesimpulan mengenai "permitting the existence of one man companies." 6

Berdasarkan fakta-fakta sebagaimana dipaparkan di atas, pelarangan pendirian PPST (dengan pengecualian untuk Perseroan dalam Pasal 7 ayat (7) UUPT) sudah tidak relevan lagi. Selain itu, hukum Perseroan di pelbagai negara juga telah menerima keberadaan PPST meskipun tidak meninggalkan bahwa Perseroan dapat didirikan secara konvensional dengan perjanjian. Pendiri

4 Anner Mangatur Sianipar, Perkembangan Hukum Perseroan Terbatas yang Berbentuk PT Perseorangan (One-Person Company), Disertasi Program Doktor Ilmu Hukum Fakultas Hukum Universitas Airlangga, Surabaya, 2017, hlm., 3.

$5 \quad$ Philip Lipton, The Mythology of Salomon's Case and the Law Dealing with the Tort Liabilities of Corporate Groups: An Historicl Perspective, Monash University Law Review, Vol. 40, No. 02, 2015, hlm., 453.

6 Ali Imanalin, Rethinking Limited Liability, Cambridge Student Law Review, Vol. 90, 2011, hlm., 90 . 
Perseroan diberi kebebasan apakah ingin mendirikan dan menjadi satu-satunya pemegang saham atau ia akan bermitra dengan pihak lain menggunakan perjanjian.

Beranjak dari latar belakang sebagaimana diuraikan di atas, rumusan masalah dalam penelitian ini adalah sebagai berikut: Mengapa UUPT mengecualikan prinsip persekutuan modal dan prinsip perjanjian hanya untuk jenis Perseroan tertentu sebagaimana dimaksud dalam Pasal 7 ayat (7)? Apakah pengecualian prinsip persekutuan modal dan prinsip perjanjian yang hanya untuk jenis Perseroan tertentu tersebut tidak bertentangan dengan keadilan? Dan Apa alasan logis untuk menjadi dasar menerima PPST tanpa perkecualian dalam hukum Perseroan Indonesia?

Tipe penelitian yang digunakan untuk menemukan jawaban atas rumusan masalah tersebut adalah penelitian hukum doktrinal. Tipe penelitian ini digunakan untuk memberikan eksposisi yang bersifat sistematis mengenai UUPT, menganalisis hubungan antara UUPT dengan undang-undang lain yang terkait PPST, serta menjelaskan bagian-bagian yang sulit untuk dipahami dari UUPT terkait PPST.7 Penelitian hukum doktrinal tersebut dilakukan dengan melakukan analisis bahan hukum primer dan bahan hukum sekunder. ${ }^{8}$ Bahan hukum primer meliputi bahan hukum primer yang memiliki otoritas, yaitu UUPT dan undangundang lain yang relevan dengan isu dalam penelitian, serta bahan hukum primer yang sifatnya persuasif, meliputi Companies Act 2006, the Civil Code of the Netherlands, the Turkish Commercial Code, Companies Law of the People's Republic of China, the Single Member Companies Rules, 2003, the Companies Act 2013, dan Federal Law No. (2) of 2015 on Commercial Companies in the United Arab Emirates. Bahan hukum sekunder merupakan bahan hukum yang menganalisis dan menjelaskan bahan hukum primer meliputi buku teks, artikel dalam jurnal, disertasi, dan tesis yang relevan dengan topik penelitian.

$7 \quad$ Terry Hutchinson, Developing Legal Research Skills: Expanding the Paradigm, Melbourne University Law Review, Vol. 32, 2008, hlm., 1068.

$8 \quad$ Terry Hutchinson. Researching and Writing in Law, Lawbook Co, Pyrmont NSW, 2002, hlm., 9. 
Selain penelitian hukum doktrinal, digunakan tipe penelitian yang berorientasi pembaruan (reform-oriented research), tujuannya untuk mengevaluasi secara intensif UUPT untuk ditemukan kekurangannya yang kemudian diberi rekomendasi untuk dilakukan perubahan. ${ }^{9}$ Inti dari reformoriented research adalah "recommends change"10 yang dalam penelitian ini rekomendasi perubahan UUPT.

\section{Pembahasan}

Pengecualian Prinsip Persekutuan Modal dan Prinsip Perjanjian Untuk Perseroan dalam Pasal 7 ayat (7) Undang-Undang Nomor 40 Tahun 2007 tentang Perseroan Terbatas

\section{Perseroan Pemegang Saham Tunggal}

Kepustakaan bahasa Inggris menyebutnya "single member company", "oneman company", "one-person company", "single member limited liability corporation", atau "societas unius personae".11 Rudhi Prasetya menamakannya sebagai PT (Perseroan Terbatas) Perorangan ${ }^{12}$, dan PT. Perseorangan oleh Anner Mangatur Sianipar.

Natcha Rattaphan mengemukakan bahwa faktanya PPST bukanlah konsep baru. Banyak pengusaha usaha perseorangan (sole proprietor) yang ingin membatasi tanggung jawab mereka dalam rangka mengurangi risiko dalam menjalankan bisnis mereka membentuk Perseroan dengan menyediakan sejumlah kecil saham kepada nomine ${ }^{13}$ untuk memenuhi persyaratan minimum jumlah pemegang saham. Nominee biasanya orang-orang yang memiliki hubungan dekat dengan pendiri Perseroan, misalnya istri, orang tua atau anak. Nominee harus

9 Terry Hutchinson, The Doctrinal Method: Incorporating Interdisciplinary Methods in Reforming the Law, Erasmus Law Review, Vol. 8, No. 3, 2015, hlm., 132.

10 Id.

11 Natcha Rattaphan, Legal Issues on Creditors' Rights and Protections in Single Member Companies, A Thesis Submitted in Partial Fulfillment of the Requirements for the Degree of Master of Laws in Business Laws (English Programs) Faculty of Law Thammasat University, Bangkok, 2016, hlm., 11.

12 Rudhi Prasetya. Kedudukan Mandiri Perseroan Terbatas Disertai dengan Ulasan Menurut Undang-Undang No. 1 Tahun 1995, Citra Aditya Bakti, Bandung, 1995, hlm., 128.

13 Orang atau badan hukum yang namanya tercatat sebagai pemegang saham tetapi bukan pemegang saham yang sebenarnya karena pemilik saham yang sebenarnya adalah pihak lain. 
orang-orang yang benar-benar dapat diandalkan oleh pemilik saham yang sebenarnya untuk tidak membahayakannya. Jenis perusahaan seperti ini disebut PPST de facto (single member company de facto). ${ }^{14}$

PPST oleh Ermias Birhanu Alaro dikatakan sebagai Perseroan yang dibentuk oleh satu orang. ${ }^{15}$ Jetu Edosa Chewaka mendefinisikan PPST sebagai Perseroan dengan pemegang saham tunggal atau hanya satu orang. ${ }^{16}$ Menurut Beihui Miao yang dimaksud PPST adalah Perseroan yang hanya memiliki satu pemegang saham baik itu perorangan (manusia) atau badan hukum. Hal ini berarti dalam PPST kepemilikan dalam perusahaan dipegang oleh pemegang saham tunggal. ${ }^{17}$

Muzaffer Eroglu memberikan definisi PPST adalah Perseroan dengan hanya satu pemegang saham. Perseroan semacam ini memiliki dua tipe. ${ }^{18}$ Pertama, "guine single member company" yang berarti Perseroan benar-benar hanya memiliki satu pemegang saham. Kedua, "de facto (substantial) single member company" dimana Perseroan semacam ini nyatanya memiliki satu pemodal dan satu atau beberapa pemegang saham yang berperan sebagai pemodal hanya untuk tujuan memenuhi persyaratan undang-undang tentang jumlah minimal pemegang saham dalam Perseroan. ${ }^{19}$

PPST memiliki karakteristik hibrida, artinya Perseroan semacam itu sama dengan perusahaan perseorangan yang hanya terdiri atas satu orang tunggal dimana stabilitas Perseroan sepenuhnya bergantung padanya, namun pemegang saham tunggal tersebut memiliki keuntungan yang sama sebagaimana pemegang saham pada Perseroan dengan pemegang saham banyak (multi-member company),

14 Natcha Rattaphan, supra no. 11, hlm., 2.

15 Ermias Birhanu Alaro. Formulate the Guiding Elements and Draft the Rules that would Help to Introduce Single Member Companies in Ethiopia, Anchor Academic Publishing, Hamburg, 2016, hlm., 13.

16 Jetu Edosa Chewaka. Introducing Single Member Companies in Ethipia Major Theoretical and Legal Considerations Hamburg: Anchor Academic Publishing, Hamburg, 2016, hlm., 13.

17 Beihui Miao, A Comparative Study of Legal Framework for Single Member Company in European Union and China, Journal of Politics and Law Vol. 5, No. 3, 2012, hlm., 2.

18 Muzaffer Eroglu, Single-Member Companies in Turkish Law, Legal Hukuk Dergisi, Vol. 64, 2008, hlm., 1.

19 Id. 
yaitu Perseroan adalah subjek hukum yang terpisah dari pemegang sahamnya. ${ }^{20}$ Dengan demikian, pemilik PPST dapat membatasi tanggung jawab mereka sesuai tingkat dana mereka sebagaimana pemegang saham pada Perseroan pemegang saham banyak. ${ }^{21}$

Perbedaan PPST dengan perusahaan perseorangan dikatakan oleh Daniel S. Kleinberger dan Carter G. Bishop bahwa:

"[A]sole proprietorship has no legal existence apart from its owner. Unlike a sole proprietorship, a sole member limited liability company is a distinct legal entity that is separate from its owner, with, for example, the power to sue and be sued in its own name."22

Karakteristik PPST yang unik itu memiliki 2 (dua) konsekuensi penting. Pertama, tidak dibutuhkan Rapat Umum Pemegang Saham sebagai organ Perseroan dengan kewenangan membuat keputusan dalam Perseroan. Berbeda dengan Perseroan pemegang saham banyak, PPST hanya memiliki satu pemegang saham sehingga tidak dibutuhkan rapat bagi pemegang saham karena ia memiliki kontrol penuh atas Perseroan. Kedua, pemegang saham dalam PPST menjalankan kekuasaan membuat keputusan sekaligus menjalankan Perseroan. ${ }^{23}$

Pada PPST, pemegang saham tunggal tidak membutuhkan pemegang saham tambahan dan dapat membuat semua keputusan Perseroan. ${ }^{24}$ Dalam Perseroan seperti itu, aturan-aturan yang lazim ada pada Perseroan seperti kuorum pada Rapat Umum Pemegang Saham dan prosedur pengambilan suara dimodifikasi, karena jelas bahwa pemegang saham tunggal tidak perlu mengadakan pertemuan formal dengan dirinya sendiri untuk mengambil keputusan yang sah. ${ }^{25}$

\footnotetext{
Natcha Rattaphan, supra no. 11, hlm., 11. Id.

2 Daniel S. Kleinberger and Carter G. Bishop, The Single-Member Limited Liability Company as Disregarded Entity, Business Law to Day, August 2, 2010, hlm., 1.

23 Natcha Rattaphan, supra no. 11, hlm., 11-12

24 Janet Dine. Company Law, Fourth Edition, Palgrave, Hampshire and New York, 2001, hlm., 6-7.

25 Id, hlm., 7.
} 


\section{Dasar Perseroan Pemegang Saham Tunggal dalam Pasal 7 ayat (7) Undang- Undang Nomor 40 Tahun 2007 tentang Perseroan Terbatas}

Sesuai ketentuan Pasal 7 ayat (7) UUPT, terdapat dua Perseroan yang dikecualikan dari prinsip persekutuan modal dan prinsip perjanjian. Pertama, Persero yang seluruh sahamnya dimiliki oleh negara. Kedua, Perseroan yang mengelola bursa efek, lembaga kliring dan penjaminan, lembaga penyimpanan dan penyelesaian, dan lembaga lain sebagaimana diatur dalam Undang-Undang Nomor 8 Tahun 1995 tentang Pasar Modal (untuk seterusnya disebut UU Pasar Modal). Menurut Nindyo Pramono, dimungkinkannya Perseroan dengan 1 (satu) pemegang saham berdasarkan ketentuan Pasal 7 ayat (7) UUPT tersebut adalah bentuk penyimpangan filososi Perseroan sebagai persekutuan modal. ${ }^{26}$

Rudhi Prasetya mengemukakan 2 (dua) sebab munculnya PPST. Pertama, pada saat perseroan didirikan diambil sahamnya oleh lebih dari satu orang tetapi kemudian hanya berada pada tangan satu orang. Terjadinya akumulasi saham pada satu orang ini dapat terjadi karena ketidaksengajaan, karena proses pertumbuhan dan perkembangan, yaitu apabila semua pemegang saham melepaskan sahamnya kepada satu orang lain atau salah seorang di antara mereka. Kedua, adanya kemungkinan sejak awal pendirian Perseroan memang telah direncanakan dan merupakan tujuan. Pemegang saham lain hanya untuk mememuhi persyaratan formal atau dengan kata lain pemegang saham lain itu sejak semula tidak sungguh-sungguh menjadi pemegang saham. ${ }^{27}$

PPST pertama berdasarkan Pasal 7 ayat (7) UUPT adalah Persero yang seluruh sahamnya dimiliki oleh negara. Penjelasan Pasal 7 ayat (7) UUPT mengemukakan alasan Persero yang seluruh sahamnya dimiliki oleh negara tidak berlaku prinsip persekutuan modal dan prinsip perjanjian karena status dan karakteristik khususnya dari Persero tersebut. Selanjutnya, Pasal 7 ayat (7) UUPT menyatakan bahwa yang dimaksud dengan Persero adalah badan usaha milik negara yang berbentuk Perseroan yang modalnya terbagi dalam saham yang

\footnotetext{
26 Nindyo Pramono, Perbandingan Perseroan Terbatas di Beberapa Negara, Badan Pembinaan Hukum Nasional Kementerian Hukum dan Hak Asasi Manusia R.I., Jakarta, 2012.

27

Rudhi Prasetya, supra no. 12, hlm., 128-129.
} 
diatur dalam Undang-Undang Nomor 19 Tahun 2003 tentang Badan Usaha Milik Negara (untuk seterusnya disebut UU BUMN). Berdasarkan Pasal 1 angka 2 UU BUMN, Persero adalah Badan Usaha Milik Negara yang berbentuk perseroan terbatas yang modalnya terbagi dalam saham yang seluruh atau paling sedikit 51\% (lima puluh satu persen) sahamnya dimiliki oleh Negara Republik Indonesia yang tujuan utamanya mengejar keuntungan.

Badan Usaha Milik Negara (untuk seterusnya disebut BUMN) adalah entitas komersial yang dimiliki atau dikontrol oleh negara. ${ }^{28}$ Pendirian BUMN (Persero) oleh Pemerintah di seluruh dunia telah menjadi kelaziman untuk tujuan-tujuan membangun infrastruktur fisik dasar; menyediakan layanan penting seperti keuangan, air, dan listrik; menghasilkan pendapatan untuk kas negara; mencapai swasembada dalam produksi barang dan jasa pokok; mengontrol sumber daya alam; mengatasi kegagalan pasar; membatasi perilaku oligopolistik; dan mempromosikan tujuan sosial seperti penciptaan lapangan kerja, pembangunan daerah, dan manfaat bagi kelompok yang kurang beruntung secara ekonomi dan sosial. ${ }^{29}$

Menurut Rudhi Prasetya, Persero tidak lain identik dengan Perseroan sehingga semua ketentuan hukum bagi Perseroan juga berlaku bagi Persero. ${ }^{30}$ Persero sebagai Perseroan pada umumnya tujuannya untuk mengejar keuntungan. Bahkan, praktik komersialisasi BUMN (Persero) semakin lazim dalam beberapa tahun terakhir dan meningkatnya harapan untuk meningkatkan kinerja, banyak Pemerintah negara-negara telah melakukan upaya untuk memprofesionalkan dewan direksi dan berusaha membuat mereka berkinerja lebih baik dengan memastikan independensi dan melindungi mereka dari

28 Fiscal Affairs Department, International Monetary Fund, Fiscal Policy How to Improve the Financial Oversight of Public Corporation, International Monetary Fund, Washington, DC, 2016, hlm.,1.

29 The World Bank, Corporate Governance of State-Owned Enterprises A Toolkit, The World Bank, Washington DC, 2014, hlm., 1-2.

30 Rudhi Prasetya, supra no. 12, hlm., 102. 
intervensi politik dalam rangka mengejar tujuan mendapatkan keuntungan finansial. ${ }^{31}$

Terlepas bahwa Persero memiliki kesamaan dengan Perseroan pada umumnya, Persero memang memiliki karakteristik yang berbeda dari Perseroan lainnya dimana Persero selain berada pada wilayah hukum privat juga tunduk pada rezim hukum publik. Karakteristik khusus inilah yang menjadi dasar Persero dilepaskan dari prinsip persekutuan modal dan prinsip perjanjian. Pertama, pendirian, pengurusan, dan pembubaran Persero menggunakan instrumen hukum publik yang pengaturannya terdapat pada Peraturan Pemerintah Nomor 45 Tahun 2005 tentang Pendirian, Pengurusan, Pengawasan, dan Pembubaran Badan Usaha Milik Negara. Kedua, hukum publik berlaku untuk Persero karena modalnya berasal dari uang negara. Selain UUPT dan UU BUMN, Undang-Undang Nomor 17 Tahun 2003 tentang Keuangan Negara, dan bahkan Undang-Undang Nomor 31 Tahun 1999 tentang Pemberantasan Tindak Pidana Korupsi sebagaimana telah diubah dengan Undang-Undang No. 20 Tahun 2001 tentang Perubahan Atas Undang-Undang Nomor 31 Tahun 1999 tentang Pemberantasan Tindak Pidana Korupsi berlaku untuk Persero. ${ }^{32}$

PPST kedua berdasarkan Pasal 7 ayat (7) UUPT adalah Perseroan yang mengelola bursa efek, lembaga kliring dan penjaminan, lembaga penyimpanan dan penyelesaian, dan lembaga lain sebagaimana diatur UU Pasar Modal. Berdasarkan UU Pasar Modal, Perseroan sebagaimana dimaksud dalam Pasal 7 ayat (7) UUPT adalah sebagai berikut:

"Bursa Efek adalah Pihak yang menyelenggarakan dan menyediakan sistem dan atau sarana untuk mempertemukan penawaran jual dan beli Efek Pihak-Pihak lain dengan tujuan memperdagangkan Efek di antara mereka (Pasal 1 angka 4 UU Pasar Modal). Lembaga Kliring dan Penjaminan adalah Pihak yang menyelenggarakan jasa kliring dan penjaminan penyelesaian Transaksi Bursa (Pasal 1 angka 9 UU Pasar Modal). Lembaga Penyimpanan dan Penyelesaian adalah Pihak yang menyelenggarakan kegiatan Kustodian

31 OECD, Professionalising Boards of Directors of State-Owned Enterprises: Stocktaking of National Practices, OECD, Paris, 2018, hlm., 7.

32 Berlakunya dua undang-undang tersebut terhadap Pesero mengingat kedua undang-undang tersebut memaknai keuangan negara meliputi uang negara yang dipisahkan, yang berarti termasuk yang ada di Persero. 
sentral bagi Bank Kustodian, Perusahaan Efek, dan Pihak lain (Pasal 1 angka 10 UU Pasar Modal). Lembaga lain sebagaimana diatur dalam UU Pasar Modal, misalnya Kustodian, Penjamin Emisi Efek, Perantara Pedagang Efek, Perusahaan Efek, dan lain sebaginya."

Menurut penjelasan Pasal 7 ayat (7) UUPT, Perseroan sebagaimana dimaksud dalam UU Pasar Modal tersebut dikecualikan dari prinsip persekutuan modal dan prinsip perjanjian karena status dan karakteristik khususnya. Perseroan-perseroan ini memiliki kedudukan khusus sebagai lembaga penunjang pasar modal dengan fungsi yang spesifik juga untuk mendukung kegiatan di pasar modal.

PPST terakhir adalah PPST di luar ketentuan Pasal 7 ayat (7) UUPT, yaitu PPST de facto. PPST jenis ini faktanya memiliki pemegang saham lebih dari 1 (satu) orang tetapi 1 (satu) di antara pemegang saham itu keberadaannya hanya untuk memenuhi formalitas pendirian Perseroan sesuai UUPT. Orang yang menjadi pemegang saham biasanya istri, anak, atau kerabat terdekat dengan jumlah saham yang relatif kecil karena sesuai tujuannya yang penting harus ada minimal 2 (dua) pemegang saham. Bentuk lainnya dapat berupa modal Perseroan dimiliki 1 (satu) orang tetapi pemilik modal ini tidak menjadi pendiri maupun pemegang saham. Orang yang menjadi pendiri dan pemegang saham pada umumnya adalah anggota keluarga atau orang kepercayaan termasuk untuk posisi direktur maupun anggota dewan komisaris. PPST de facto sejak awal memang direncanakan untuk menjadi PPST. Pendirian Perseroan semacam ini dilandasi motivasi sekadar mengambil manfaat atas karakteristik Perseroan tetapi sesungguhnya Perseroan ini secara material merupakan usaha perorangan (one man business) ${ }^{33}$ walaupun kenyataannya memiliki lebih dari 1 (satu) pemegang saham.

\section{Pengecualian Prinsip Persekutuan Modal dan Prinsip Perjanjian Hanya untuk Perseoan dalam Ketentuan Pasal 7 ayat (7) Undang-Undang Nomor 40 Tahun 2007 tentang Perseroan Terbatas bertentangan dengan Keadilan}

33 Rudhi Prasetya, supra no. 12, hlm., 129. 


\section{Hukum dan Keadilan}

Hukum dan keadilan tidak dapat dipisahkan sebagaimana diktum klasik terkenal St. Augustinus yang menyatakan bahwa "lex inusta non est lex" atau "unjust law is not law", artinya hukum yang tidak adil bukanlah hukum. ${ }^{34}$ Pernyataan klasik lain mengenai hukum dan keadilan menyatakan bahwa hukum yang sangat tidak adil dapat dan harus ditolak untuk memiliki karakteristik hukum, setiap orang dan hakim, secara moral dan yuridis berhak memperlakukannya seolah-olah sebagai bukan hukum. ${ }^{35}$

John Rawl dalam magnum oppus-nya, A Theory of Justice, mengemukakan bahwa keadilan adalah kebajikan pertama dari institusi sosial dan sebagai kebenaran sistem pemikiran. Betapapun sebuah teori sangat anggun dan ekonomisnya harus ditolak atau diperbaiki jika tidak benar, demikian juga hukum dan institusi, tidak peduli seberapa efisien dan tertata dengan baik harus direformasi atau dihapuskan jika tidak adil. Setiap orang memiliki kebebasan yang didirikan atas dasar keadilan yang bahkan kesejahteraan masyarakat secara keseluruhan tidak dapat ditimpakan kepadanya. Karena alasan ini keadilan menyangkal bahwa hilangnya kebebasan bagi sebagian orang dibenarkan oleh kebaikan yang lebih besar yang dimiliki oleh orang lain. ${ }^{36}$

Hukum tanpa keadilan akan membuat masyarakat politik yang baik akan menurun menjadi tirani atau anarki. ${ }^{37}$ Bahkan dikatakan oleh Adam Smith bahwa keadilan adalah pilar utama yang menopang bangunan besar masyarakat manusia, jika keadilan tidak ada, tatanan masyarakat manusia suatu saat akan hancur. ${ }^{38}$

34 Andrei Marmor, The Nature of Law An Introduction, dalam Andrei Marmor (Ed), The Routledge Companian to Philosophy of Law, Routledge Taylor \& Francis Group, New York and London 2012, hlm., 13.

35 Robert Alexy, Some Reflections on the Ideal Dimension of Law and on the Legal Philosophy of John Finnis, The American Journal of Jurisprudence, Vol. 58, No.2, 2013, hlm. 107.

36 John Rawls, A Theory of Justice, Revised Edition, The Belknap Press of Harvard University Press, Cambridge, Massachusetts, 1999, hlm., 3.

37 Darrell Dobbs, The Justice of Socrates's Philosopher Kings, American Journal of Political Science, Vol. 29, No. 4, November 1985, hlm., 809.

38 Knud Haakonssen, The Science of A Legislator the Natural Jurisprudence of David Hume and Adam Smith, Cambridge University Press, Cambirdge, 1981, hlm., 87. 


\section{Ketentuan Pasal 7 ayat (7) Undang-Undang Nomor 40 Tahun 2007 tentang Perseroan Terbatas Bertentangan dengan Keadilan}

Bahwa ketentuan Pasal 7 ayat (7) UUPT bertentangan dengan keadilan akan dianalisis dari teori keadilan Aristoteles. Istilah "keadilan" menurut Aristoteles memiliki dua pengertian. ${ }^{39}$ Pertama, keadilan berarti suatu perilaku yang sesuai dengan hukum, yaitu perilaku yang sesuai dengan aturan perilaku manusia yang tetap dan berwibawa. Singkatnya, keadilan merupakan suatu perilaku yang sesuai dengan apapun yang merupakan instrumen otoritatif kontrol sosial dan moral. Keadilan pertama ini merujuk pada kepatuhan terhadap aturan otoritatif tertentu dari perilaku manusia, dan disebut sebagai keadilan moral (moral justice), yaitu suatu kebajikan yang diperlihatkan kepada orang lain sebagai suatu kebajikan sosial. Kedua, keadilan menandakan kesetaraan (equality) atau tepatnya menunjuk pada sesuatu yang fair. Keadilan dalam arti yang kedua ini yang terutama menarik minat Aristoteles karena ini merupakan konsep yang dengannya hukum bekerja serta dapat lebih spesifik untuk dievaluasi, dan bukan sekadar perilaku moral manusia.

Dari dua konsep keadilan Aristoteles, keadilan sebagai kesetaraan atau fair yang memiliki relevansi dengan pengkajian ini. Kesetaraan merujuk pada fair dan perlakuan yang sama untuk semua orang. ${ }^{40}$ Kesetaraan adalah konsep etika yang sangat kabur namun penting, ide dasarnya adalah bahwa setiap orang harus diperlakukan sama, misalnya persamaaan kesempatan. ${ }^{41}$ Kesetaraan, khususnya dalam hukum, kekuasaan, atau status politik. ${ }^{42}$

Aristoteles menggunakan kesetaraan dalam dua pengertian. Pertama, kesetaraan dimaknai secara sederhana sebagai "excellence" atau "goodness" yang berlawanan dengan "bad". Istilah-istilah ini digunakan Aristoteles untuk merujuk

39 Anton-Hermann Chroust and David L. Osborn, Aristotle's Conception of Justice, Notre Dame Law Review, Vol. 17,Issue 2, 1942, hlm., 129-130.

40 PAM Peters, The Cambridge Guide to English Usage, Cambridge University Press, Cambridge, 2004, hlm., 186.

41 Michael Proudfoot and A.R. Lacey, The Routledge Dictionary of Philosophy, Fourth Edition, Routledge, London and New York, 2010, hlm., 123.

42 Bryan A. garner (Editor in Chief), Black's Law Dictionary, Thomson West, St. Paul, MN, 2004, hlm., 576. 
pada suatu kebajikan tertentu, yang secara umum disebut kebajikan dari keadilan, sebagai suatu kebaikan jenis tertentu. Kedua, kesetaraan merupakan suatu perbaikan hukum, dimana hukum gagal karena universalitasnya. ${ }^{43}$

Menurut Aristoteles, kesetaraan berarti "fair mean" atau "ideal mean" antara apa yang lebih baik dan yang apa yang buruk. Kesetaraan menjadi kriteria umum untuk pelaksanaan perilaku manusia, suatu konsep, terutama berhubungan dengan rasio proporsional dari "commensurable goods" dan dengan mana "law in action" dapat secara lebih spesifik untuk dievaluasi. ${ }^{44}$ Prinsip kesetaraan merujuk sebagai prinsip sosial karena mengacu pada hubungan manusia dengan dengan manusia lainnya, dengan mewujudkan kebaikan kepada orang lain atau melakukan apa yang menguntungkan bagi orang lain. ${ }^{45}$

Prinsip kesetaraan memiliki dua aspek utama. ${ }^{46}$ Pertama, ditunjukkan dalam tindakan mendistribusikan hal-hal tertentu antara dua orang atau lebih, atau menyesuaikan masalah-masalah tersebut dengan rasio yang tepat. Aspek pertama dari prinsip kesetaraan ini disebut keadilan distributif (distributive justice), yaitu prinsip yang menuntut bahwa hanya yang setara diperlakukan sama dan yang selalu "kesetaraan proporsional", yaitu bentuk keadilan yang membagikan beban sesuai dengan kemampuan individu dan mendukung dalam jumlah yang bervariasi sesuai kebutuhan masing-masing individu. Kedua, keadilan komutatif (commutative justice) yang berlawanan dengan keadilan distributif yang mengabaikan perbedaan kedudukan dan kelayakan orang-orang yang terlibat di dalamnya, hanya berdasarkan rasio proporsional antara dua "commensurable goods", seperti buruh dan upah, atau kerusakan dan pemulihan. Perbedaan mendasar dua aspek utama dari prinsip kesetaraan tersebut ditemukan dalam perbedaan antara kesetaraan dengan orang-orang yang terlibat dan kesetaraan tanpa memandang orang dan kedudukannya, antara gagasan bahwa setiap orang harus memiliki hak sesuai kedudukan dan nilainya dan gagasan bahwa perlakuan

43 Roger A. Shiner, Aristotle's Theory of Equity, Loyola of Los Angeles Law Review, Vol. 27, 1994, hlm., 1247.

44 Anton-Hermann Chroust, Aristotle's Conception of Equity (Epieikeia), Notre Dame Law Review, Vol, 18, Issue 2, 1942, hlm., 119.

45 Id, hlm., 119-120.

46 Id, hlm., 120-121. 
yang sama berlaku untuk semua orang terlepas dari kedudukan dan nilai mereka. ${ }^{47}$

Pasal 7 ayat (7) UUPT tidak adil karena gagal mendistribusikan persamaan hak dan kesempatan kepada orang-orang untuk melakukan tindakan dengan tujuan yang sama. Pasal 7 ayat (7) UUPT memperlakukan berbeda kepada orang yang mendirikan Perseroan yang tujuannya sama untuk mengejar keuntungan.

\section{Alasan Logis Sebagai Dasar Menerima Perseroan Pemegang Saham Tunggal Tanpa Perkecualian dalam Hukum Perseroan Indonesia}

Perseroan Pemegang Saham Tunggal di Inggris, Jerman, Prancis, Belanda, Turki, Amerika Serikat, Cina, Pakistan, India, Singapura, dan Uni Emirat Arab

Inggris adalah negara pertama yang membuka jalan untuk PPST melalui yurisprudensi kasus terkenal Salomon v. Salomon \& Co. pada 1897.48 Akhirnya, pada 1925, Inggris memberikan statutory status pada konsep PPST sehingga dengan demikian menjadi suatu pembaruan. ${ }^{49}$ Pada saat ini PPST diatur dalam Companies Act 2006. Section 7 (1) menetapkan "a company is formed under this Act by one or more persons." Section 7 (2) menetapkan "a company may not be so formed for an unlawful purpose."

Di Jerman, PPST (Einmanngesellschaft) diakui sejak reformasi hukum pada 1980.50 Prancis mengakui PPST (Entreprise unipersonnelle à responsabilité limitée) sejak 1985 dalam rangka menyelesaikan permasalahan praktik pembentukan Perseroan yang mensyaratkan adanya minimal 2 (dua) pemegang saham. ${ }^{51}$

Di Belanda, PPST diatur dalam Article 64 (2) the Civil Code of the Netherlands yang menetapkan sebagai berikut:

\footnotetext{
Id, hlm., 121.

48 Neha Yati and Krusch. PA, One Person Company in India, International Journal of Law and Legal Jurisprudence Studies, Vol.2, Issue 4, 2005, hlm., 7. 
"A company is incorporated by one or more persons by notarial deed. For incorporation a certificate from the Minister of Justice is required that there have appeared to be no objections. The deed must be signed by each incorporator and by each person who appears from the deed to have subscribed to one or more shares." 52

Di Turki, berdasarkan the Turkish Commercial Code, sejak 2012 Perseroan dapat dibentuk oleh satu atau beberapa pemegang saham. ${ }^{53}$ Sebelumnya, sesuai ketentuan Article 504 of the Turkish Commercial Code, Perseroan paling sedikit harus memiliki 2 (dua) pemegang saham. ${ }^{54}$

Di Amerika Serikat, sejak 1996 Perseroan dapat memiliki 1 (satu) pemegang saham yang kemudian dikenal sebagai "single member limited liability company". Negara bagian Florida menerima konsep PPST pada 1982, California pada 2000, dan pada 2003 diterima di Massachusetts. ${ }^{55}$

Cina mengakui kedudukan hukum dan mengadopsi PPST dalam undangundang mereka ketika Companies Law of the People's Republic of China telah direvisi dan mulai berlaku efektif sejak 1 Januari 2006.56 PPST diatur dalam Section 3 tentang Special Provisions on One-person Companies with Limited Liability terdiri atas Article 58-64. Berdasarkan Article 58 yang dimaksud PPST adalah "company with limited liability where there is only one shareholder who is a natural person or a legal person."

Pakistan mengatur PPST dalam the Single Member Companies Rules, 2003. Menurut Section 2 (b) yang dimaksud PPST adalah "a private company which has only one member." Berdasarkan the Single Member Companies Rules, 2003, dibedakan dua macam PPST, yaitu Perseroan yang dibentuk sebagai PPST dan Perseroan dengan lebih dari satu pemegang saham kemudian menjadi PPST setelah memenuhi ketentuan berdasarkan the Single Member Companies Rules, 2003.

52 Hans Warendorf, Richard Thomas, and Ian Curry-Sumner. The Civil Code of the Netherlands, Kluwer Law International, Alphen aan den Rijn, 2009, hlm., 287.

53 Neha Yati and Krusch. PA, supra no. 35, hlm., 8.

54 Muzaffer Eroglu, supra no. 22, hlm., 2.

55 Natcha Rattaphan, supra no. 15, hlm., 10.

56 Beihui Miao, supra no. 21, hlm., 1. 
Di India, pengaturan PPST terdapat pada the Companies Act 2013. Berdasarkan Sub-Section 62 of Section 2, yang dimaksud dengan PPST adalah " $a$ company which has only one person as a member where all the legal and financial liabilities are limited to the company and not to its members." 57 Berdasarkan undang-undang sebelumnya, yaitu the Companies Act 1956, Perseroan paling sedikit harus memiliki 2 (dua) pemegang saham. ${ }^{58}$

Singapura mengakui PPST berdasarkan Companies Act hasil revisi pada 2006. Berdasarkan Section 20A Companies Act, Perseroan paling sedikit memiliki 1 (satu) pemegang saham.

Di Uni Emirat Arab, PPST diperkenalkan berdasarkan Federal Law No. (2) of 2015 on Commercial Companies in the United Arab Emirates. Pada Article 71 (2) ditetapkan bahwa "one citizen, whether natural or artificial person, may incorporate and own a limited liability company, and owner of company's capital shall be held liable only the extent of the capital stated in its MOA, and shall be subject to provisions of limited liability company enumerated in this law, without any contradictions with the nature of the company." Berdasarkan undang-undang lama, yaitu the United Arab Emirates Commercial Companies Law No. 8 of 1984, Perseroan dilarang hanya memiliki 1 (satu) pemegang saham tetapi juga tidak boleh melebihi memiliki 50 (lima puluh) pemegang saham.

\section{Pendirian Perseroan Pemegang Saham Tunggal Tanpa Perkecualian dalam Hukum Perseroan Indonesia}

Pendirian PPST tanpa perkecualian atau tidak hanya terbatas sebagaimana ketentuan Pasal 7 ayat (7) UUPT harus diawali dengan merevisi UUPT. Pada revisi atau pembuatan UUPT baru di waktu yang akan datang dibuat ketentuan baru bahwa Perseroan selain didirikan secara konvensional berdasarkan prinsip persekutuan modal dan prinsip perjanjian juga dapat didirikan dalam bentuk PPST. Orang yang akan mendirikan badan usaha dalam bentuk Perseroan

\footnotetext{
57 Namrata Gupta, One Person Company-A Critical Analysis, International Journal of Legal Insight Vol. I, Issue 3, 2014, hlm., 12.

58

Id.
} 
diberikan kebebasan untuk memilih antara bermitra dengan orang lain atau mendirikan Perseroan sendirian.

Penerimaan PPST tanpa perkecualian pada UUPT pada masa yang akan datang berdasarkan beberapa alasan. Pertama, alasan filosofis. Membolehkan mendirikan PPST tanpa perkecualian berarti telah mendistribusikan kesetaraan hak dan kesempatan kepada semua orang tanpa membedakan status atau kedudukannya atau faktor lainnya. Pendirian Perseroan oleh siapapun dilandasai tujuan yang sama untuk mengejar keuntungan sehingga tidak layak untuk tidak diberi hak dan kesempatan yang sama. Selain itu, hak untuk memperoleh perlakukan yang sama di hadapan hukum telah dinormakan menjadi hak hukum (legal right) yang dijamin oleh ketentuan Pasal 28D ayat (1) Undang-Undang Dasar Negara Republik Indonesia Tahun 1995.

Kedua, alasan praktis. Alasan ini berdasarkan hasil perbandingan dengan hukum Perseroan Inggris, Jerman, Prancis, Belanda, Turki, Amerika Serikat, Cina, Pakistan, India, Singapura, dan Uni Emirat Arab yang telah mengadopsi PPST. Ketiga, penerimaan PPST tanpa perkecualian untuk melegitimasikan apa yang telah ada dalam praktik di masyarakat, yaitu PPST de facto dimana Perseroan didirikan dan memiliki minimal 2 (dua) pemegang saham tetapi hanya sekadar memenuhi formalitas UUPT, esensinya Perseroan seperti itu merupakan PPST. UUPT harus menyesuaikan diri dengan perkembangan dan memenuhi kebutuhan hukum dalam masyarakat.

Penerimaan PPST tanpa perkecualian memberikan manfaat baik dari perspektif pengusaha maupun publik. Dari perspektif pengusaha, manfaat dari PPST meliputi:

1. PPST menjadi alternatif bagi pengusaha yang enggan untuk berinvestasi dengan pengusaha lain dalam membangun bisnis mereka sendiri.

2. Oleh karena tidak perlu menunjuk nominee untuk memegang saham bagi mereka, tidak akan ada konflik kepentingan atau masalah kepercayaan di antara pemegang saham. Tidak akan ada konflik dalam pengelolaan bisnis karena pemegang saham tunggal melakukan kontrol Perseroan secara penuh. Dia dapat membuat semua keputusan bisnis secara independen dan menerima semua keuntungan dari Perseroan. 
3. Pemegang saham tunggal hanya perlu mencurahkan lebih sedikit waktu, energi, dan sumber daya untuk bisnisnya karena rezim PPST lebih sederhana.

4. PPST dianggap sebagai alat untuk melindungi aset pribadi karena prinsip subjek hukum yang terpisah. PPST dapat membatasi tanggung jawab pribadi pemegang sahamnya sehingga akan mendorong mereka untuk berinvestasi lebih banyak lagi dalam bisnisnya dengan pengetahuan bahwa mereka tidak akan bertanggung jawab secara pribadi atas utang Perseroan.

5. Dari perspektif sebaliknya, karena PPST merupakan subjek hukum yang terpisah maka aset mereka terlindungi dari tuntutan terhadap pribadi pemegang sahamnya. Perseroan dilindungi dari kesulitan keuangan pemiliknya.

6. PPST lebih dapat dipercaya daripada perusahaan perseorangan karena mereka harus mematuhi beberapa peraturan dan membuka informasi penting kepada publik. Orang-orang yang berkepentingan dapat mengakses informasi tersebut sebelum memutuskan untuk terlibat dalam transaksi bisnis dengan PPST. ${ }^{59}$

Sementara itu bagi publik, manfaat dari keberadaan PPST adalah sebagai berikut:

1. PPST saat ini dikenal dan diterima sebagai model bisnis dan pengakuan konsep ini secara tepat telah mencerminkan tren bisnis saat ini.

2. Pemerintah akan dapat secara efektif mengatur dan mengawasi jenis Perseroan ini yang kemudian akan mendorong mereka untuk transparan sehingga mereka akan membayar pajaknya secara benar. Pada saat yang sama, pemerintah dapat mendorong pertumbuhan ekonomi dengan memberikan beberapa keuntungan eksklusif bagi PPST tersebut.

3. Kemudahan mendirikan PPST akan mendorong individu untuk memulai bisnis baru yang berarti akan meningkatkan peluang atas pekerjaan peluang untuk dan mendorong pertumbuhan ekonomi secara keseluruhan. 60

A.M. Sianipar mengemukakan bahwa keuntungan dari PPST meliputi:

1. Pendiriannya lebih mudah dan simpel karena tidak melibatkan banyak pihak;

2. Cocok untuk usaha mikro kecil dan menengah yang memiliki modal terbatas;

3. Biaya untuk pendirian dan pengoperasiannya bisa dibuat lebih hemat;

4. Manajemen dan struktur organisasinya lebih sederhana; dan

59 Natcha Rattaphan, supra no. 15, hlm. ,13-14. 
5. Pengambilan keputusan bisnis lebih cepat;

6. Perlakukan perpajakan yang lebih simpel. ${ }^{61}$

\section{Doktrin Piercing the Corporate Veil}

Janet Dine menyatakan bahwa intisari dari Perseroan adalah kedudukannya sebagai subjek hukum yang terpisah dari orang-orang yang membentuknya. Hal ini berarti meskipun orang-orang yang menjalankan Perseroan terus berubah, Perseroan tetap pada identitasnya dan bisnis tidak perlu dihentikan dan dimulai kembali dengan setiap adanya perubahan manajer maupun pemegang saham.62 Perseroan sebagai subjek hukum tidak hanya memiliki uang sendiri yang berbeda dari uang orang-orang yang menjalankan Perseroan, tetapi pemegang saham Perseroan juga tidak bertanggung jawab untuk utang Perseroan. Pemegang saham hanya dapat diminta untuk membayar utang Perseroan sesuai dari nilai saham mereka63

UUPT pada Pasal 3 ayat (1) menegaskan bahwa pemegang saham Perseroan tidak bertanggung jawab secara pribadi atas perikatan yang dibuat atas nama Perseroan dan tidak bertanggung jawab atas kerugian Perseroan melebihi saham yang dimiliki. Penjelasan Pasal 3 ayat (1) tersebut menerangkan bahwa ketentuan Pasal 3 ayat (1) mempertegas ciri Perseroan bahwa pemegang saham hanya bertanggung jawab sebesar setoran atas seluruh saham yang dimilikinya dan tidak meliputi harta kekayaan pribadinya.

Kedudukan Perseroan sebagai subjek hukum tersendiri inilah yang oleh Janet Dine dikatakan dapat memiliki beberapa akibat yang tidak terduga dan kadang tidak diinginkan. ${ }^{64}$ Perseroan dapat dimanfaatkan atau disalahgunakan sebagai alter ego atau instrumen belaka oleh pemilik atau pemegang saham di mana pemilik atau pemegang saham itu menggunakan Perseroan untuk melakukan tindakan yang merugikan Perseoan sendiri atau pihak ketiga yang

\footnotetext{
Anner Mangatur Sianipar, supra no. 1, hlm., 77.

Janet Dine, supra no. 28, hlm., 22.

Id.

Id, hlm., 28.
} 
memiliki hubungan dengan perseroan. ${ }^{65}$ Perseroan dibentuk untuk satu alasan sederhana, yaitu untuk melindungi diri dari tanggung jawab. Dalam beberapa kasus, status Perseroan disalahgunakan. ${ }^{66}$ Dalam kondisi seperti itu, doktrin alter ego membolehkan diterapkannya doktrin piercing the corporate veil dimana para pengurus Perseroan harus bertanggung jawab secara pribadi atas 'perbuatan dosa' yang dilakukannya atas nama Perseroan. ${ }^{67}$

PPST dengan hanya 1 (satu) pemegang saham yang memiliki kontrol penuh atas Perseroan sangat rentan dan potensial untuk menjadi alter ego. Untuk mencegah hal itu terjadi sekaligus untuk perlindungan pihak ketiga di situ doktrin piercing the corporate veil menjalankan fungsinya. Selain itu, Anner Mangatur Sianipar menyarankan pemerintah dapat membuat peraturan tambahan seperti kewajiban mempublikasikan laporan keuangan yang diaudit akuntan publik minimal 2 (dua) kali dalam 1 (satu) tahun secara periodik per semester68 untuk mencegah kekhawatiran PPST hanya akan menjadi alter ego untuk kepentingan pribadi pemegang sahamnya.

Menurut doktrin piercing the corporate veil pengadilan akan mengabaikan kemandirian Perseroan sebagai subjek hukum dan pemegang saham harus bertanggung jawab secara pribadi untuk tindakan dan utang Perseroan. ${ }^{69}$ Pengadilan dapat menerapkan doktrin piercing the corporate veil ketika "the corporation is so controlled as to be the alter ego or mere instrumentality of its owners."70

Dalam UUPT, doktrin piercing the corporate veil dapat diterapkan kepada pemegang saham sebagaimana diatur pada Pasal 3 ayat (2), bagi direksi sesuai Pasal 95 ayat (4) dan (5), Pasal 97 ayat (3), Pasal 101 ayat (2), dan untuk komisaris berdasarkan Pasal 114 ayat (2) dan Pasal 115 ayat (1). Dari praktik peradilan, doktrin piercing the corporate veil pernah diterapkan dalam Putusan

65 Jennifer J. Hagan, The Alter-Ego Doctrine Exception in California Corporate Law, The Hagan Law Firm, 2007, hlm., 1.

66 Daniel T. McCloskey, Alter Ego: Piercing the Corporate Veil, California Lawyer, 2008, hlm., 42.

67 Id.

68 Anner Mangatur Sianipar,supra no.1, hlm., 95.

69 Michael A. Thomason, "Piercing the Corporate Veil," Facts \& Findings, 2011, hlm., 20.

70 Id. 
Mahkamah Agung No. 1916 K/Pdt/1991 dalam Perkara PT. Bank Perkembangan Asia melawan PT. Djaja Tunggal. Pertimbangan hukum Mahkamah Agung menyatakan bahwa pemberian kredit dari PT. Bank Perkembangan Asia kepada PT. Djaja Tunggal, suatu perusahaan yang dimiliki oleh bank tersebut, menimbulkan dugaan adanya persekongkolan dan itikad buruk pada diri tergugat dengan penggugat (Bank). Kasus yang demikian itu, menurut ajaran hukum termasuk piercing the corporate veil yaitu pembatalan pertanggungjawaban yang terbatas dari suatu perseroan dapat dibebankan kepada para pengurusnya, apabila tindakan hukum yang mereka lakukan untuk dan atas nama perseroan mengandung persekongkolan dengan itikad buruk yang menimbulkan kerugian bagi pihak lain. ${ }^{71}$

\section{Penutup}

Pengecualian prinsip persekutuan modal dan prinsip perjanjian untuk Perseroan dalam ketentuan Pasal 7 ayat (7) UUPT berdasarkan alasan, untuk Persero karena status dan karakteristik khususnya di mana Persero selain berada dalam wilayah hukum privat juga tunduk pada hukum publik. Selain pendirian, pengurusan, dan pembubarannya menggunakan instrumen hukum publik, modal Persero juga berasal dari dana publik (keuangan negara). Untuk Perseroan yang mengelola bursa efek, lembaga kliring dan penjaminan, lembaga penyimpanan dan penyelesaian, dan lembaga lain sebagaimana diatur UU Pasar Modal, juga dikecualikan dari prinsip persekutuan modal dan prinsip perjanjian karena status dan karakteristik khususmya, yaitu kedudukannya sebagai lembaga penunjang pasar modal dengan fungsi khususnya untuk mendukung kegiatan di pasar modal.

Pengecualian prinsip persekutuan modal dan prinsip perjanjian secara terbatas hanya untuk Perseroan dalam ketentuan Pasal 7 ayat (7) UUPT melanggar keadilan. Pasal 7 ayat (7) UUPT tidak mendistribusikan prinsip kesetaraan dengan tidak memberikan perlakuan yang sama kepada orang atas suatu perbuatan yang sama dan dengan tujuan yang sama, yaitu pendirian Perseroan untuk mengejar keuntungan.

${ }^{71}$ Varia Peradilan XIV, 1999, hlm. 28. 
Penerimaan PPST tanpa perkecualian pada UUPT di waktu mendatang berdasarkan alasan filosofis dan alasan praktis. Alasan filosofis untuk mewujudkan keadilan dengan menerapkan perlakuan yang sama atas dasar kesetaraan hak dan kesempatan bagi semua orang dalam hal pendirian Perseroan. Sementara itu, alasan praktis dengan mengadopsi pengalaman hukum Perseroan negara lain yang telah menerima PPST tanpa perkecualian. Alasan praktis lainnya, yaitu UUPT harus mengikuti dan memenuhi perkembangan serta kebutuhan hukum dalam masyarakat terhadap PPST.

Penerimaan PPST tanpa perkecualian, selain menciptakan keadilan, juga untuk memudahkan kegiatan berbisnis. Orang tidak lagi harus mencari mitra (yang belum tentu cocok untuk bekerja sama tetapi terpaksa dilakukan karena perintah undang-undang) untuk menjalankan bisnisnya dan tidak perlu lagi mendirikan PPST de facto. UUPT dengan mengadopsi PPST tanpa perkecualian akan menjadi UUPT modern, karena UUPT di pelbagai negara lain telah mereformasi Perseroan yang pada mulanya harus didirikan dan memiliki lebih dari 1 (satu) pemegang saham, berubah menjadi memilih antara Perseroan konvensional (Perseroan dengan minimal 2 (dua) pemegang saham) atau PPST.

\section{Daftar Pustaka}

\section{Buku:}

Andrei Marmor, The Nature of Law An Introduction, dalam Andrei Marmor (Ed), The Routledge Companian to Philosophy of Law, Routledge Taylor \& Francis Group, New York and London 2012.

Anthony Mancuso, Nolo's Quiick LLC, 4th Edition, Nolo, California, 2007.

Bryan A. Garner (Editor in Chief), Black's Law Dictionary, Thomson West, St. Paul, $M N, 2004$.

Ermias Birhanu Alaro, Formulate the Guiding Elements and Draft the Rules that would Help to Introduce Single Member Companies in Ethiopia, Anchor Academic Publishing, Hamburg, 2016. 
Fiscal Affairs Department, International Monetary Fund, Fiscal Policy How to Improve the Financial Oversight of Public Corporation, International Monetary Fund, Washington,DC, 2016.

Hans Warendorf, Richard Thomas, and Ian Curry-Sumner, The Civil Code of the Netherlands, Kluwer Law International, Alphen aan den Rijn, 2009.

Janet Dine, Company Law, Fourth Edition, Palgrave, Hampshire and New York, 2001. Jetu Edosa Chewaka, Introducing Single Member Companies in Ethipia Major Theoretical and Legal Considerations, Anchor Academic Publishing, Hamburg, 2016.

John M.B. Balouziyeh, A Legal Guide to United States Business Organizations The Law of Partnership, Corporations, and Limited Liability Companies, Second Edition, Springer, Heidelberg, 2013.

John Rawls, A Theory of Justice, Revised Edition, The Belknap Press of Harvard University Press, Cambridge, Massachusetts, 1999.

Knud Haakonssen, The Science of A Legislator the Natural Jurisprudence of David Hume and Adam Smith, Cambridge University Press, Cambirdge, 1981.

Michael Proudfoot and A.R. Lacey, The Routledge Dictionary of Philosophy, Fourth Edition, Routledge, London and New York, 2010.

Nicholas Bourne, Essential Company Law, Third Edition, Cavendish Publishing Limited, London and Sydney, 2000.

Nindyo Pramono, Perbandingan Perseroan Terbatas di Beberapa Negara, Badan Pembinaan Hukum Nasional Kementerian Hukum dan Hak Asasi Manusia R.I., Jakarta, 2012.

PAM Peters, The Cambridge Guide to English Usage, Cambridge University Press, Cambridge, 2004.

OECD, Professionalising Boards of Directors of State-Owned Enterprises: Stocktaking of National Practices, OECD, Paris, 2018.

Rudhi Prasetya, Kedudukan Mandiri Perseroan Terbatas Disertai dengan Ulasan Menurut Undang-Undang No. 1 Tahun 1995, Citra Aditya Bakti, Bandung, 1995.

Terry Hutchinson, Researching and Writing in Law, Lawbook Co, Pyrmont NSW, 2002.

The World Bank, Corporate Governance of State-Owned Enterprises A Toolkit, The World Bank, Washington DC, 2014.

\section{Jurnal:}

Ali Imanalin, "Rethinking Limited Liability," Cambridge Student Law Review, 90: 9099, 2011.

Anton-Hermann Chroust, "Aristotle's Conception of Equity (Epieikeia)", Notre Dame Law Review, 18:2, 119-128, 1942.

Anton-Hermann Chroust and David L. Osborn, "Aristotle's Conception of Justice", Notre Dame Law Review, 17:2:129-143, 1942.

Beihui Miao, "A Comparative Study of Legal Framework for Single Member Company in European Union and China", Journal of Politics and Law 5:1-14, 2012.

Bryant Smith, Legal Personality, Suspicions News Magazine, 12: 79-99, 1926. 
Daniel S. Kleinberger and Carter G. Bishop, "The Single-Member Limited Liability Company as Disregarded Entity," Business Law to Day, 1-3, 2010.

Daniel T. McCloskey, "Alter Ego: Piercing the Corporate Veil," California Lawyer, 4245, 2008.

Darrell Dobbs, "The Justice of Socrates's Philosopher Kings", American Journal of Political Science, 29:4: 809-826, 1985.

David Millon, "Theories of the Corporation", Duke Law Journal, 1990: 201-262.

Jennifer J. Hagan, "The Alter-Ego Doctrine Exception in California Corporate Law," The Hagan Law Firm, 1-6, 2007.

Marie-Laure Djelic, "When Limited Liability was (Still) an Issue: Mobilization and Politics of Signification in 19th-Century England," Organization Studies 34: 595-621, 2013.

Michael A. Thomason, "Piercing the Corporate Veil," Facts \& Findings, 28-29, 2011.

Muzaffer Eroglu, "Single-Member Companies in Turkish Law," Legal Hukuk Dergisi 64: 1-20, 2008.

Namrata Gupta, "One Person Company-A Critical Analysis," International Journal of Legal Insight I: 11-20, 2014.

Neha Yati and Krusch. PA, "One Person Company in India, "International Journal of Law and Legal Jurisprudence Studies 2:1-39, 2005.

Philip Lipton, "The Mythology of Salomon's Case and the Law Dealing with the Tort Liabilities of Corporate Groups: An Historicl Perspective," Monash University Law Review 40: 452-487, 2015.

Robert Alexy, "Some Reflections on the Ideal Dimension of Law and on the Legal Philosophy of John Finnis", The American Journal of Jurisprudence, 58:2: 97110, 2013.

Roger A. Shiner, Aristotle's Theory of Equity, Loyola of Los Angeles Law Review, 27: 1245-1264, 1994.

Terry Hutchinson, "Developing Legal Research Skills: Expanding the Paradigm," Melbourne University Law Review 32:1065-1095, 2008.

Terry Hutchinson, "The Doctrinal Method: Incorporating Interdisciplinary Methods in Reforming the Law," Erasmus Law Review 8:130-138, 2015.

\section{Disertasi/Tesis:}

Anner Mangatur Sianipar, "Perkembangan Hukum Perseroan Terbatas yang Berbentuk PT Perseorangan (One-Person Company)", Disertasi Program Doktor Ilmu Hukum Fakultas Hukum Universitas Airlangga, Surabaya, 2017.

Natcha Rattaphan, Legal Issues on Creditors' Rights and Protections in Single Member Companies, A Thesis Submitted in Partial Fulfillment of the Requirements for the Degree of Master of Laws in Business Laws (English Programs) Faculty of Law Thammasat University, Bangkok, 2016.

\section{Peraturan Perundang-undangan:}

Undang-Undang Dasar Negara Republik Indonesia Tahun 1945. 
Undang-Undang No. 8 Tahun 1995 tentang Pasar Modal (Lembaran Negara Republik Indonesia Tahun 1995 Nomor 64; Tambahan Lembaran Negara Republik Indonesia Nomor 3608).

Undang-Undang Nomor 31 Tahun 1999 tentang Pemberantasan Korupsi (Lembaran Negara Republik Indonesia Tahun 1999 Nomor 140; Tambahan Lembaran Negara Republik Indonesia Nomor 3874).

Undang-Undang No. 20 Tahun 2001 tentang Perubahan Atas Undang-Undang No.

31 Tahun 1999 tentang Pemberantasan Tindak Pidana Korupsi (Lembaran

Negara Republik Indonesia Tahun 2001 Nomor 134; Tambahan Lembaran

Negara Republik Indonesia Nomor 4150).

Undang-Undang Nomor 17 Tahun 2003 tentang Keuangan Negara (Lembaran Negara Republik Indonesia Tahun 2003 Nomor 47; Tambahan Lembaran Negara Republik Indonesia Nomor 4286).

Undang-Undang No. 19 Tahun 2003 tentang Badan Usaha Milik Negara (Lembaran Negara Republik Indonesia Tahun 2003 Nomor 70; Tambahan Lembaran Negara Republik Indonesia Nomor 4297).

Undang-Undang No. 40 Tahun 2007 tentang Perseroan Terbatas (Lembaran Negara Republik Indonesia Tahun 2007 Nomor 106; Tambahan Lembaran Negara Republik Indonesia Nomor 4756).

Peraturan Pemerintah No. 45 Tahun 2005 tentang Pendirian, Pengurusan, Pengawasan, dan Pembubaran Badan Usaha Milik Negara (Lembaran Negara Republik Indonesia Tahun 2005 Nomor 117; Tambahan Lembaran Negara Republik Indonesia Nomor 4556 Tahun 2005).

The Civil Code of the Netherlands

The Companies Act 2006

The Companies Act 2013

The Companies Law of the People's Republic of China

The Federal Law No. (2) of 2015 on Commercial Companies in the United Arab Emirates.

The Single Member Companies Rules, 2003

The Turkish Commercial Code 